\title{
Convergence of Inflammatory Pathways in Allergic Asthma and Sickle Cell Disease
}

\author{
Amali E. Samarasinghe ${ }^{1,2,3+}$ and Jason W. Rosch ${ }^{4 * t}$ \\ ${ }^{1}$ Division of Pulmonology, Allergy-Immunology, and Sleep, Department of Pediatrics, College of Medicine, University of \\ Tennessee Health Science Center, Memphis, TN, United States, ${ }^{2}$ Department of Microbiology Immunology and \\ Biochemistry, College of Medicine, University of Tennessee Health Science Center, Memphis, TN, United States, ${ }^{3}$ Children's \\ Foundation Research Institute, Memphis, TN, United States, ${ }^{4}$ Department of Infectious Diseases, St. Jude Children's \\ Research Hospital, Memphis, TN, United States
}

OPEN ACCESS

Edited by:

Nadeem Khan,

University of North Dakota,

United States

Reviewed by:

Bibhuti Mishra,

University of Massachusetts

Medical School, United States

Timothy J. Chapman,

Rochester Regional Health,

United States

${ }^{*}$ Correspondence:

Jason W. Rosch

jason.rosch@stjude.org

tThese authors have contributed equally to this work

Specialty section:

This article was submitted to Inflammation,

a section of the journal

Frontiers in Immunology

Received: 29 October 2019 Accepted: 16 December 2019 Published: 24 January 2020

Citation:

Samarasinghe AE and Rosch JW (2020) Convergence of Inflammatory

Pathways in Allergic Asthma and

Sickle Cell Disease.

Front. Immunol. 10:3058.

doi: 10.3389/fimmu.2019.03058
The underlying pathologies of sickle cell disease and asthma share many characteristics in terms of respiratory inflammation. The principal mechanisms of pulmonary inflammation are largely distinct, but activation of common pathways downstream of the initial inflammatory triggers may lead to exacerbation of both disease states. The altered inflammatory landscape of these respiratory pathologies can differentially impact respiratory pathogen susceptibility in patients with sickle cell disease and asthma. How these two distinct diseases behave in a comorbid setting can further exacerbate pulmonary complications associated with both disease states and impact susceptibility to respiratory infection. This review will provide a concise overview of how asthma distinctly affects individuals with sickle cell disease and how pulmonary physiology and inflammation are impacted during comorbidity.

Keywords: sickle cell disease (SCD), asthma, acute chest syndrome (ACS), respiratory infection, pulmonary inflammation

\section{INTRODUCTION}

Red blood cells (RBCs) constitute the largest number of mobile cells in the human body (about $3 \times 10^{12}$ ) that perform the primary function of $\mathrm{O}_{2}\left(\right.$ and $\left.\mathrm{CO}_{2}\right)$ transportation through hemoglobin $\mathrm{Hb}$. Alterations that occur in $\mathrm{Hb}$ through inherited genes can lead to a change in RBC morphology and function leading to sickle cell disease (SCD), a common inherited disorder leading to anemia, incidences of vaso-occlusive crises, acute chest syndrome (ACS), cumulative organ damage, and a number of additional chronic comorbidities (1). A large number of individuals carry the sickle cell trait, wherein a single sickle cell gene ("S") is inherited, and are mostly asymptomatic (2). However, a patient with two sickle genes are named to have the HbSS form of SCD, while a patient who inherits one $S$ gene and another abnormal hemoglobin gene (C, beta thalassemia, D, E, or O) will have alternate types of SCD such as HbSC or HbS beta thalassemia. Patients with SCD represent a significant health care burden in terms of cost, and despite a number of therapeutic strategies, life expectancy in this population remains decades premature compared to that of the general population (3-5). As the most commonly inherited blood disease, SCD affects $>100,000$ in the United States and millions more worldwide (6). With 1:13 babies born with the sickle cell trait and 1:365 patients having SCD, African Americans have the highest incidence of SCD in the U.S. (7). The high occurrence of pulmonary complications in SCD patients has led to the consideration of possible complications from other respiratory conditions that have similar symptomatologies, like asthma. 
Asthma is a syndrome of the respiratory system that affects 26 million Americans and 300 million globally. Like SCD, the incidence of asthma is predicted to continue to increase as indicated by the $3.6 \%$ increase in prevalence since 2006 (8). Of note is the observation that individuals with SCD have an increased incidence of asthma when compared to the general population. In children, the incidence of asthma diagnosis is as high as $27 \%$ in individuals with SCD (9). Approximately $30-70 \%$ of patients with SCD also suffer from asthma $(10,11)$ leading to a poorer quality of life. Like SCD, African Americans (especially women) are more likely to have asthma and African American children have a much higher likelihood of dying from asthma compared to other ethnicities (12). While it is unclear why asthma incidence is disproportionately elevated in African American children with SCD, socioeconomic factors and perhaps even overdiagnosis of asthma in SCD patients may contribute to this bias. ACS, one of the most frequent complications of SCD, is correlated with the incidence of asthma in the SCD population (13-15). As such, gaining an understanding of the clinical and immunological consequences of asthma in the context of SCD is of critical importance for improving patient outcomes in this patient group.

Asthma and SCD share a number of similarities in terms of the immunological factors associated with their respective disease states. Both conditions result in inflammation and airway hyperreactivity, both conditions impact susceptibility to respiratory infections, and both require specific interventions to mitigate the complications associated with them. Despite the recognition that asthma in the context of SCD likely results in a comorbid condition distinct from the general population, there is relatively little mechanistic insight into how these two disease pathologies co-function. In this review we highlight the potential immunological synergies between asthma and SCD garnered from both clinical data and murine modeling studies to showcase how these conditions may exacerbate each other, thereby representing a unique comorbid condition in these highrisk patient populations.

\section{IMMUNOLOGIC CONSEQUENCES OF ASTHMA IN SCD}

The immunologic sequelae associated with SCD and asthma are complex but have some overlap. Given that both asthma and SCD impact inflammation in distinct ways, the interplay into how these two conditions function when present in a comorbid state raises important questions. Elevated IgE levels in children with SCD is much more common than in the general population and is associated with both asthma and increased morbidity in children (9). Increased serum IgE is a well-accepted biomarker of allergic asthma, and SCD patients have elevated IgE in sera which may occur as a result of non-specific immune activation in these patients, leading to a $\mathrm{T}_{\mathrm{H}} 2$ bias and increased risk for asthma as a consequence. This enhanced serum IgE availability is also reflected in murine models, whereby the increase in total IgE in sensitized SCD mice is significantly greater than what is observed in sensitized wild type animals (16). Pulmonary function testing is often utilized to distinguish allergic asthma from other IgE mediated inflammatory conditions. Adult patients with SCD have a high incidence, up to $80 \%$, of abnormal pulmonary function when tested (17). A similar, but less severe pattern is observed in children with SCD, with $\sim 50 \%$ of patients having abnormal results (18). Abnormal results were more prevalant in the asthmatic pediatric SCD patients, underscoring applicability of pulmonary function analysis as part of making an appropriate diagnosis of asthma in SCD patients (18). The utility of screening for respiratory disorders such as asthma in children and adults using pulmonary function tests has not been fully established and current guidelines suggest routine collection of a thorough respiratory history to identify pulmonary disease in patients with SCD. This is of particular importance in young children because pulmonary function tests can be unreliable in this population. While asthma represents a major and frequent health concern for patients with SCD, the mechanistic factors driving the development and immunological features of asthma in the context of SCD remain poorly elucidated and create barriers to appropriate asthma management in SCD patients.

Endothelial activation is considered to be a major pathway by which sickled RBCs contribute to vaso-occlusion. Sickled RBC binding to integrins on endothelial cells lead to injury via reactive oxygen species that also function in a feed-forward loop to continue to activate endothelial cells (19). This activation leads to the infiltration of other cells such as monocytes and neutrophils which contribute to uncontrolled cell adhesion that occurs in blood vessels of SCD patients $(20,21)$. Increased levels of proinflammatory cytokines such as IL-3, GM-CSF, and PGE2 have also been noted to occur in SCD patients (22-24). Steady state levels of TNF- $\alpha$, IL- $\alpha$, IL- $1 \beta$, and IL- 6 are all elevated in SCD (23-25). Elevated neutrophil counts are characteristic of SCD and can form neutrophil extracellular traps in the pulmonary vasculature, contributing to acute lung injury resulting from inflammatory cytokine signaling (26). Both the pulmonary and systemic responses to inflammatory stimuli are greatly elevated in the context of SCD with enhanced levels of TNF- $\alpha$, IL- $1 \beta$, s-VCAM-1 being observed following endotoxin treatment (27). This heightened inflammatory landscape contributes to multiple complications of SCD, ranging from pulmonary disfunction and infection susceptibility.

Airway inflammation is a canonical hallmark of asthma and eosinophils may dominate as the infiltrating leukocyte in severe allergic asthma. Endothelial activation is fundamental to the initiation of inflammation in asthma (28) wherein endothelial cells upregulate integrins and selectins in response to allergenic stimuli (29) and cytokines produced in situ by resident leukocytes (30). Markers of endothelial activation including ICAM-1, VCAM-1, P-selection, and E-selectin are also elevated in the context of $\operatorname{SCD}(24,31)$. Similarly, IL3 and GM-CSF can promote the allergic milieu (32) and support activation and survival of eosinophils in the airways (33). While the exact role of PGE2 in the lungs of asthmatics is still unclear, its elevation correlates with eosinophilia (34). Common inflammatory pathways between SCD and asthma may therefore lead to an asthma-like phenotype in patients with 
SCD (Figure 1), or indeed, increase the likelihood of asthma pathogenesis in these patients.

\section{MODELING ASTHMA AND SCD IN MICE}

While SCD is a hereditary condition, asthma development is dependent on genetic and environmental components. Although rodents do not naturally develop asthma, asthma-like disease can be triggered in them through continuous exposure to natural aeroallergens or ovalbumin (OVA) (35). The possible overlap between asthma and SCD based on shared symptoms such as airway inflammation, hyperresponsiveness, and architectural damage has created a demand for animal models of asthma and SCD comorbidity, although only a few have been created to date using OVA and house dust mite (HDM) as triggering allergens.

Existing models of asthma in SCD mice after OVA sensitization and challenge suggest that mice with SCD respond more severely to allergen exposures $(16,36,37)$. OVA exposure leads to the development of peribronchovascular inflammation (with active eosinophils) and inflammatory foci, elevated serum IgE, and bronchial epithelial hyperplasia in BERK SCD mice to equivalent levels as wild-type controls (16). However, more severe pathologic changes occur in SCD mice when OVA-challenge duration is prolonged causing death in about $30 \%$ of the animals (16), suggesting that the BERK SCD mice may have a lower threshold for asthma exacerbation. Using a bone marrow chimeric mouse model of SCD and shortened exposures to aerosolized OVA, Pritchard et al. demonstrated that OVA-induced allergic inflammation in these SCD mice correlates with a heightened $\mathrm{T}_{\mathrm{H}} 2$ cytokine milieu and pulmonary tissue resistance marked by a decrease in lung tissue elasticity suggestive of greater alveolar occlusion (36). This trend in airway inflammation and general $\mathrm{T}_{\mathrm{H}} 2$ skewing was recapitulated by Andemariam et al. using the BERK mouse model of SCD and a more standard model of OVA exposure (37). Of note, naïve BERK SCD have increased levels of $\mathrm{T}_{\mathrm{H}}$ 2-type cytokines in the bronchoalveolar lavage fluid and a higher number of T-lymphocytes in the lungs (37). Airway hyperresponsiveness is a shared hallmark of SCD and asthma $(38,39)$, that generally correlates with pulmonary inflammation. Despite heightened airway inflammation in response to OVA, BERK SCD mice had lower airway reactivity compared to wild-type mice even at very high doses of methacholine (37), suggesting that inflammation and airway hyperresponsiveness may be disjointed in SCD.

Although OVA is a commonly used trigger to induce allergic asthma-like disease in mice, due to its limitations as a clinically relevant aeroallergen, utilization of more relevant allergens such as HDM, cockroach, fungal, and viral antigens have gained popularity among investigators that model asthma in mice (40). Most recently, Jiang et al. found no differences between BERK SCD and wild-type mice in the inflammatory index, airway cytokines, or HDM-specific IgE levels after HDM exposure (41). These findings are exciting

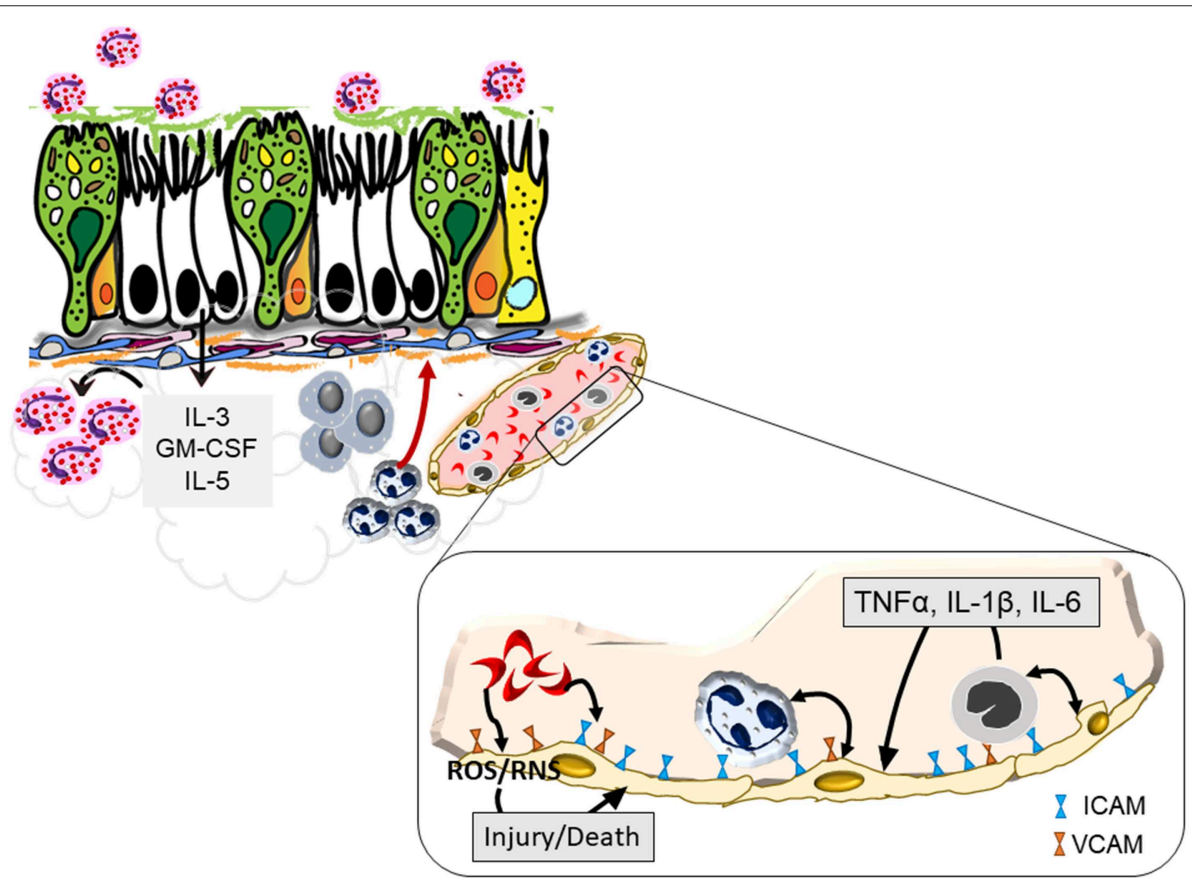

FIGURE 1 | Endothelial activation by sickled red blood cells that may exacerbate asthma. Sickled red cells induce endothelial upregulation of integrins, ICAM, and VCAM, that enhance attachment and subsequent infiltration of neutrophils and monocytes into the pulmonary tissue. Increased margination of these leukocytes trigger further interaction with endothelial cells through the production of pro-inflammatory cytokines that together with sickled red blood cells cause endothelial cell production of reactive oxygen and nitrogen species that can trigger blood vessel injury. Recruited cells further activate the bronchial epithelium leading to a positive feedback loop to promote heightened inflammation and airway hyperreactivity. 
as they confirm that variation in outcome occurs based on the antigen, route of exposure, and adjuvants in SCD mice. Mouse models of SCD with asthma that can be used to decipher mechanisms that underlie asthma pathogenesis in patients with SCD is an important gap in technology to address.

\section{TREATMENT OF ASTHMA IN INDIVIDUALS WITH SICKLE CELL DISEASE}

Information amassed on the immunologic basis of asthma has resulted in the development of biologics targeted for patients with specific endotypes. However, since the efficacy of these therapeutics are quite low, corticosteroids are used to alleviate the symptoms during asthma attacks despite our knowledge of the long term negative impact of steroids on human health (42). Although the SCD-asthma comorbid condition is prevalent, relatively little evidence based models exist for its management. Current models for asthma management in SCD are based on $\mathrm{NIH}$ guidelines for the general population and include liberal use of inhaled steroids, despite the extensive literature recognizing SCD patients as a uniquely susceptible and vulnerable patient population $(10,43,44)$. Use of inhaled steroids further increases the risk of colonization of $S$. pneumoniae which may increase the likelihood for the development of invasive disease to which the SCD population is particularly susceptible $(45,46)$. Inhaled corticosteroids have been proposed to be used to prevent additional episodes of vaso-occlusive crisis in pediatric patients, and recent studies have underscored the feasibility of this approach in young children (47). Inhaled steroids given to nonasthmatic patients with SCD have demonstrated considerable promise, with significant reductions in pain and sVCAM levels as well as inflammatory macrophage markers, underscoring the potential for targeting inflammation to improve health outcomes in these patients (48-50). Whether treatments for specific asthma endotypes can be extended to patients with SCD remains unclear, though given the underlying differences in inflammation tailored therapeutic strategies may be required.

\section{SCD AND ASTHMA: INDEPENDENT PATHWAYS TO INFECTION SUSCEPTIBILITY}

Asthma and SCD both fundamentally alter susceptibility and immune responses to respiratory infection. Patients with SCD are overwhelmingly susceptible to multiple respiratory pathogens, most importantly the pneumococcus $(51,52)$, and infectious diseases increase the development of ACS in these patients (5355). The heightened sensitivity to infection is recapitulated in the murine model of SCD, whereby the SCD mice demonstrate dramatically enhanced susceptibility to both bacterial and viral respiratory infections (56-58). This issue can be further confounded by strains outside of vaccine coverage causing invasive disease in these patients, as is the case with $S$. pneumoniae (59). Immunogenic responses to vaccines in SCD patients may also be suboptimal to confer effective protection as the responses have been reported to wane more rapidly to a number of serotypes included in the current pneumococcal vaccines, an observation that has been recapitulated in murine models of SCD $(60,61)$. These underscore the importance of appropriate prophylactic strategies to mitigate infection risk in individuals with SCD.

Similar but distinct to what is observed in the context of SCD, allergic asthma dramatically also alters susceptibility to multiple respiratory pathogens including both viral and bacterial pathogens (62). However, unlike in the case of SCD, allergic asthma has been found to confer both sensitivity and resistance to subsequent respiratory infection, wherein outcomes are more likely to be dependent on the type of pathogen. Asthma exacerbations triggered by rhinoviruses and respiratory syncytial virus, for example, can be detrimental to the host (63), while asthma exacerbations triggered by influenza virus infection is tolerated by the host which also exhibit reduced signs of influenza morbidity and enhanced viral clearance $(64,65)$. Immune responses to viruses in hosts with asthma may be dependent on a multitude of factors including gender, age, virus strain and prior exposures, endotype of asthma, and environmental factors including pollution and nutrition. How these alterations in pulmonary inflammation during the asthma-SCD comorbid state differentially impact the risk of infection remains poorly understood, though given the distinct nature of these two disease settings, it may be anticipated that together they impact infection susceptibility in a manner distinct from the general population.

\section{ANTIBIOTIC EXPOSURE AND ASTHMA}

Due to the propensity of patients with SCD to develop fulminant lethal sepsis caused by $S$. pneumoniae, during childhood, penicillin prophylaxis is prescribed for all children with SCD until the age of 5 years, which has dramatically improved mortality in this patient population prior to the advent of the pneumococcal conjugate vaccine (66-70). There is considerable evidence linking antibiotic exposure to the development of childhood asthma and other allergic disease in the general population, though there are challenges in terms of confounding respiratory infections (71-79). Early antibiotic use is associated with allergic asthma in young children even when accounting for bias inherent from antibiotic prescriptions to treat early symptoms of asthma; this is predictable as bacterial colonization of the respiratory and gastrointestinal tract are critical mediators that shape susceptibility to allergic airway inflammation (8082). These effects may be amplified in SCD patients due to the prolonged exposure to antibiotics.

Administering penicillin to patients with SCD eliminates several bacterial species from the nasal-oral microbiota (83). Exposure to antibiotics early in life can have long lasting consequences on the developing bacterial microbiome $(84,85)$. Bacterial colonization of the respiratory and gastrointestinal tract are critical mediators that can shape susceptibility to allergic airway inflammation (82). Numerous gaps in knowledge including alterations that may naturally occur in the microbiome of the SCD host (86), the relative impact of long-term penicillin 
prophylaxis on the intestinal and respiratory flora of these patients, and whether this long-term prophylaxis also impacts the likelihood of subsequent asthma development preclude our understanding of disease pathogenesis in SCD patients and those that may develop asthma.

\section{ARGININE DEFICIENCY: A COMMON CROSSROAD IN SCD AND ASTHMA PATHOPHYSIOLOGY}

Arginine deficiency has long been recognized as an important aspect of SCD pathophysiology $(87,88)$. Low arginine bioavailability is associated with a multitude of complications in SCD including pulmonary hypertension and vaso-occlusive pain episodes (89-91). The decreased arginine availability in SCD is severe enough to impact the contribution of bacterial arginine biosynthesis and uptake pathways to virulence (57). Due to the multiple facets of host pathophysiology, arginine supplementation has been proposed as a therapeutic intervention for $\operatorname{SCD}(92,93)$. Arginine supplementation has been suggested as a means by which to alleviate complications in patients with SCD and improve overall health $(94,95)$. Clinical trials further support the potential for arginine supplementation to confer benefit in SCD individuals in terms of endothelial function and to induce nitric oxide production during vaso-occlusive crisis $(93,96)$.

Arginine deficiency is a common feature underlying the pathophysiology of both allergic asthma and SCD (Figure 2).
Murine models of allergic asthma have demonstrated that arginine deficiency to nitric oxide synthase (NOS) results in deficiencies in nitric oxide, a bronchodilator, in tandem with increased peroxynitrite, a pro-contractile molecule, both of which contribute to airway hyperresponsiveness in the context of asthma. Polycation secretion by eosinophils, which are dramatically elevated in allergic asthma, can inhibit arginine uptake via the $y+\operatorname{system}(97,98)$. In the context of SCD, there are additional mechanisms underlying arginine deficiency that are independent of pathways operative during asthma. The increased hemolysis of RBCs leads to the release of cellular arginase which can scavenge arginine prior to cellular uptake. In the context of asthma and SCD comorbidity, heightened baseline inflammation may lead to increased expression of both iNOS and arginase, thereby further depleting cellular arginine pools (99). As such, the extracellular arginase released by hemolysis coupled with the increased pulmonary eosinophil infiltrate inhibiting arginine uptake are likely to have an additive effect. Likewise, the increased arginase and iNOS activity resulting from increased levels of inflammatory cytokines inherent in both SCD and allergic asthma, are also potentially synergistic in terms of arginine depletion. Due to the divergence of many of these arginine depleting pathways, it would be expected that such deficiency may be synergistic in comorbid patients with SCD and asthma.

The benefits conferred by arginine supplementation may be most evident in comorbid patients with both SCD and asthma due to the non-overlapping mechanisms of arginine deficiency.

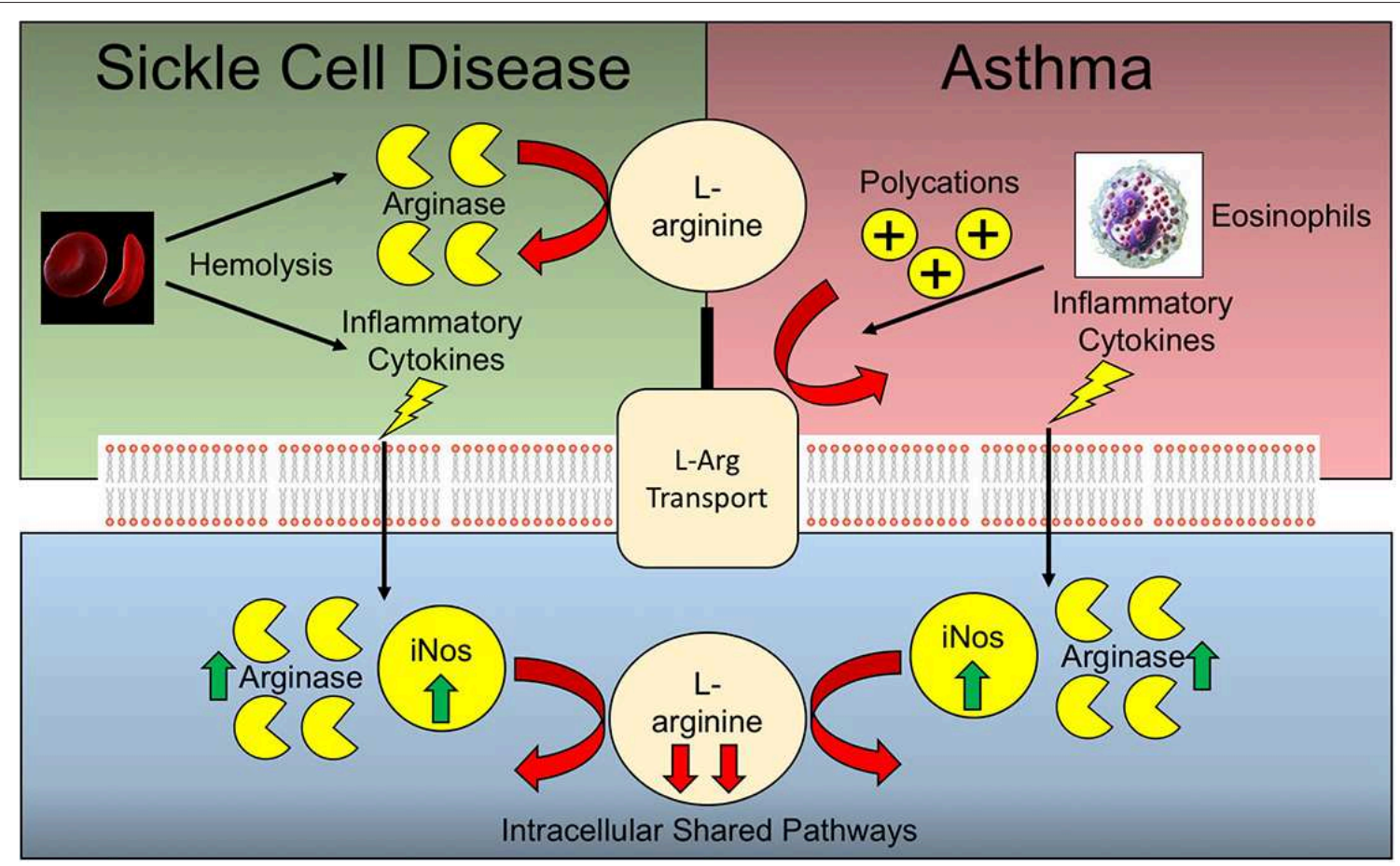

FIGURE 2 | Arginine deficiencies in Sickle cell disease and asthma. Sickle cell disease and asthma share complementary and potentially synergistic mechanisms of arginine deficiency. Many of the pathways operative extracellularly are different, while the intracellular pathways are shared. 


\section{DISCUSSION}

SCD and asthma share similar manifestations in terms of airway hyperreactivity despite being immunologically distinct diseases. Experimental modeling and clinical data suggest that asthma impacts individuals with SCD in a specific manner distinct from the general population. Laying a mechanistic foundation for understanding pulmonary complications of sickle cell disease and how these complications can be rationally targeted in a SCD-specific manner may provide novel opportunities for treatment. Given the unique host pathophysiology that underlies SCD, these individuals

\section{REFERENCES}

1. Platt OS, Brambilla DJ, Rosse WF, Milner PF, Castro O, Steinberg MH, et al. Mortality in sickle cell disease. Life expectancy and risk factors for early death. N Engl J Med. (1994) 330:1639-44. doi: 10.1056/NEJM199406093302303

2. Ojodu J, Hulihan MM, Pope SN, Grant AM, Centers for Disease Control and Prevention. Incidence of sickle cell trait-United States, 2010. MMWR Morb Mortal Wkly Rep. (2014) 63:1155-8.

3. Kauf TL, Coates TD, Huazhi L, Mody-Patel N, Hartzema AG. The cost of health care for children and adults with sickle cell disease. Am J Hematol. (2009) 84:323-7. doi: 10.1002/ajh.21408

4. Elmariah H, Garrett ME, De Castro LM, Jonassaint JC, Ataga KI, Eckman JR, et al. Factors associated with survival in a contemporary adult sickle cell disease cohort. Am J Hematol. (2014) 89:530-5. doi: 10.1002/ajh.23683

5. Telen MJ, Malik P, Vercellotti GM. Therapeutic strategies for sickle cell disease: towards a multi-agent approach. Nat Rev Drug Discov. (2018) 18:13958. doi: 10.1038/s41573-018-0003-2

6. Rees DC, Williams TN, Gladwin MT. Sickle-cell disease. Lancet. (2010) 376:2018-31. doi: 10.1016/S0140-6736(10)61029-X

7. Centers for Disease Control Sickle Cell Disease (SCD) (2019). Available online at: https://www.cdc.gov/ncbddd/sicklecell/index.html (accessed October 22, 2019).

8. Network GA. The Global Asthma Report 2018. Auckland: Global Asthma Network (2018).

9. An P, Barron-Casella EA, Strunk RC, Hamilton RG, Casella JF, Debaun MR. Elevation of IgE in children with sickle cell disease is associated with doctor diagnosis of asthma and increased morbidity. J Allergy Clin Immunol. (2011) 127:1440-6. doi: 10.1016/j.jaci.2010.12.1114

10. Morris CR. Asthma management: reinventing the wheel in sickle cell disease. Am J Hematol. (2009) 84:234-41. doi: 10.1002/ajh.21359

11. Debaun MR, Strunk RC. The intersection between asthma and acute chest syndrome in children with sickle-cell anaemia. Lancet. (2016) 387:2545-53. doi: 10.1016/S0140-6736(16)00145-8

12. Akinbami LJ, Moorman JE, Liu X. Asthma prevalence, health care use, and mortality: United States, 2005-2009. Natl Health Stat Report. (2011) 32:1-14.

13. Boyd JH, Macklin EA, Strunk RC, Debaun MR. Asthma is associated with acute chest syndrome and pain in children with sickle cell anemia. Blood. (2006) 108:2923-7. doi: 10.1182/blood-2006-01-011072

14. Bernaudin F, Strunk RC, Kamdem A, Arnaud C, An P, Torres M, et al. Asthma is associated with acute chest syndrome, but not with an increased rate of hospitalization for pain among children in France with sickle cell anemia: a retrospective cohort study. Haematologica. (2008) 93:1917-8. doi: 10.3324/haematol.13090

15. Debaun MR, Rodeghier M, Cohen R, Kirkham FJ, Rosen CL, Roberts I, et al. Factors predicting future ACS episodes in children with sickle cell anemia. Am J Hematol. (2014) 89:E212-17. doi: 10.1002/ajh.23819

16. Nandedkar SD, Feroah TR, Hutchins W, Weihrauch D, Konduri KS, Wang J, et al. Histopathology of experimentally induced asthma in a murine model of sickle cell disease. Blood. (2008) 112:2529-38. doi: 10.1182/blood-2008-01-132506 may benefit from tailored interventions for the treatment of asthma.

\section{AUTHOR CONTRIBUTIONS}

JR and AS wrote the manuscript jointly.

\section{FUNDING}

AS was partially funded through the NIH, NIAID 1R01AI125481, and the Plough Foundation. JR was partially funded through ALSAC, NIAID 1U01-AI124302, and 1R01-AI110618.

17. Lunt A, Desai SR, Wells AU, Hansell DM, Mushemi S, Melikian N, et al. Pulmonary function, CT and echocardiographic abnormalities in sickle cell disease. Thorax. (2014) 69:746-51. doi: 10.1136/thoraxjnl-2013-204809

18. Intzes S, Kalpatthi RV, Short R, Imran H. Pulmonary function abnormalities and asthma are prevalent in children with sickle cell disease and are associated with acute chest syndrome. Pediatr Hematol Oncol. (2013) 30:72632. doi: 10.3109/08880018.2012.756961

19. Canalli AA, Costa FF, Saad ST, Conran N. Granulocytic adhesive interactions and their role in sickle cell vaso-occlusion. Hematology. (2005) 10:419-25. doi: 10.1080/10245330500141259

20. Belcher JD, Marker PH, Weber JP, Hebbel RP, Vercellotti GM. Activated monocytes in sickle cell disease: potential role in the activation of vascular endothelium and vaso-occlusion. Blood. (2000) 96:2451-9. doi: 10.1182/blood.V96.7.2451

21. Belcher JD, Chen C, Nguyen J, Zhang P, Abdulla F, Nguyen P, et al. Control of oxidative stress and inflammation in sickle cell disease with the Nrf2 activator dimethyl fumarate. Antioxid Redox Signal. (2017) 26:748-62. doi: 10.1089/ars.2015.6571

22. Conran N, Saad ST, Costa FF, Ikuta T. Leukocyte numbers correlate with plasma levels of granulocyte-macrophage colony-stimulating factor in sickle cell disease. Ann Hematol. (2007) 86:255-61. doi: 10.1007/s00277-006-0246-6

23. Croizat $\mathrm{H}$. Circulating cytokines in sickle cell patients during steady state. $\mathrm{Br}$ J Haematol. (1994) 87:592-7. doi: 10.1111/j.1365-2141.1994.tb08318.x

24. Graido-Gonzalez E, Doherty JC, Bergreen EW, Organ G, Telfer M, Mcmillen MA. Plasma endothelin-1, cytokine, and prostaglandin E2 levels in sickle cell disease and acute vaso-occlusive sickle crisis. Blood. (1998) 92:2551-5. doi: 10.1182/blood.V92.7.2551

25. Malave I, Perdomo Y, Escalona E, Rodriguez E, Anchustegui M, Malave $\mathrm{H}$, et al. Levels of tumor necrosis factor alpha/cachectin (TNF alpha) in sera from patients with sickle cell disease. Acta Haematol. (1993) 90:172-6. doi: 10.1159/000204452

26. Chen G, Zhang D, Fuchs TA, Manwani D, Wagner DD, Frenette PS. Hemeinduced neutrophil extracellular traps contribute to the pathogenesis of sickle cell disease. Blood. (2014) 123:3818-27. doi: 10.1182/blood-2013-10529982

27. Holtzclaw JD, Jack D, Aguayo SM, Eckman JR, Roman J, Hsu LL. Enhanced pulmonary and systemic response to endotoxin in transgenic sickle mice. Am J Respir Crit Care Med. (2004) 169:687-95. doi: 10.1164/rccm.200302-224OC

28. Green CE, Turner AM. The role of the endothelium in asthma and chronic obstructive pulmonary disease (COPD). Respir Res. (2017) 18:20. doi: 10.1186/s12931-017-0505-1

29. Asosingh K, Weiss K, Queisser K, Wanner N, Yin M, Aronica M, et al. Endothelial cells in the innate response to allergens and initiation of atopic asthma. J Clin Invest. (2018) 128:3116-28. doi: 10.1172/JCI97720

30. Toews GB. Cytokines and the lung. Eur Respir J Suppl. (2001) 34:3s-17s. doi: 10.1183/09031936.01.00266001

31. Lebensburger JD, Howard T, Hu Y, Pestina TI, Gao G, Johnson M, et al. Hydroxyurea therapy of a murine model of sickle cell anemia inhibits the progression of pneumococcal disease by down-modulating E-selectin. Blood. (2012) 119:1915-21. doi: 10.1182/blood-2011-08-374447 
32. Asquith KL, Ramshaw HS, Hansbro PM, Beagley KW, Lopez AF, Foster PS. The IL-3/IL-5/GM-CSF common receptor plays a pivotal role in the regulation of Th2 immunity and allergic airway inflammation. J Immunol. (2008) 180:1199-206. doi: 10.4049/jimmunol.180.2.1199

33. Tomaki M, Zhao LL, Sjostrand M, Linden A, Ichinose M, Lotvall J. Comparison of effects of anti-IL-3, IL-5 and GM-CSF treatments on eosinophilopoiesis and airway eosinophilia induced by allergen. Pulm Pharmacol Ther. (2002) 15:161-8. doi: 10.1006/pupt.2001.0333

34. Profita M, Sala A, Bonanno A, Riccobono L, Siena L, Melis MR, et al. Increased prostaglandin E2 concentrations and cyclooxygenase-2 expression in asthmatic subjects with sputum eosinophilia. J Allergy Clin Immunol. (2003) 112:709-16. doi: 10.1016/S0091-6749(03)01889-X

35. Aun MV, Bonamichi-Santos R, Arantes-Costa FM, Kalil J, Giavina-Bianchi P. Animal models of asthma: utility and limitations. J Asthma Allergy. (2017) 10:293-301. doi: 10.2147/JAA.S121092

36. Pritchard KA Jr., Feroah TR, Nandedkar SD, Holzhauer SL, Hutchins W, Schulte ML, et al. Effects of experimental asthma on inflammation and lung mechanics in sickle cell mice. Am J Respir Cell Mol Biol. (2012) 46:389-96. doi: 10.1165/rcmb.2011-0097OC

37. Andemariam B, Adami AJ, Singh A, Mcnamara JT, Secor ER, Guernsey LA, et al. The sickle cell mouse lung: proinflammatory and primed for allergic inflammation. Transl Res. (2015) 166:254-68. doi: 10.1016/j.trsl.2015.03.001

38. Field JJ, Stocks J, Kirkham FJ, Rosen CL, Dietzen DJ, Semon T, et al. Airway hyperresponsiveness in children with sickle cell anemia. Chest. (2011) 139:563-8. doi: 10.1378/chest.10-1243

39. Chapman DG, Irvin CG. Mechanisms of airway hyper-responsiveness in asthma: the past, present and yet to come. Clin Exp Allergy. (2015) 45:706-19. doi: $10.1111 /$ cea.12506

40. Kumar RK, Herbert C, Foster PS. Mouse models of acute exacerbations of allergic asthma. Respirology. (2016) 21:842-9. doi: 10.1111/resp.12760

41. Jiang C, Gavitt TD, Szczepanek SM. House dust mite-induced allergic lung inflammation is not exacerbated in sickle cell disease Mice. Int Arch Allergy Immunol. (2019) 179:192-200. doi: 10.1159/000499043

42. Buchman AL. Side effects of corticosteroid therapy. J Clin Gastroenterol. (2001) 33:289-94. doi: 10.1097/00004836-200110000-00006

43. Sobota A, Graham DA, Heeney MM, Neufeld EJ. Corticosteroids for acute chest syndrome in children with sickle cell disease: variation in use and association with length of stay and readmission. Am J Hematol. (2010) 85:24-8. doi: 10.1002/ajh.21565

44. Gomez E, Morris CR. Asthma management in sickle cell disease. Biomed Res Int. (2013) 2013:604140. doi: 10.1155/2013/604140

45. Leikin SL, Gallagher D, Kinney TR, Sloane D, Klug P, Rida W. Mortality in children and adolescents with sickle cell disease. Cooperative Study of Sickle Cell Disease. Pediatrics. (1989) 84:500-8.

46. Zhang L, Prietsch SO, Mendes AP, Von Groll A, Rocha GP, Carrion L, et al. Inhaled corticosteroids increase the risk of oropharyngeal colonization by Streptococcus pneumoniae in children with asthma. Respirology. (2013) 18:272-7. doi: 10.1111/j.1440-1843.2012.02280.x

47. Vance Utset L, Ivy Z, Willen SM, Rodeghier M, Watt A, Schilling L, et al. Inhaled corticosteroid use to prevent severe vaso-occlusive episode recurrence in children between 1 and 4 years of age with sickle cell disease: a multicenter feasibility trial. Am J Hematol. (2018) 93:E101-3. doi: 10.1002/ajh. 25033

48. Glassberg J, Minnitti C, Cromwell C, Cytryn L, Kraus T, Skloot GS, et al. Inhaled steroids reduce pain and sVCAM levels in individuals with sickle cell disease: a triple-blind, randomized trial. Am J Hematol. (2017) 92:622-31. doi: 10.1002/ajh.24742

49. Carden MA, Little J. Emerging disease-modifying therapies for sickle cell disease. Haematologica. (2019) 104:1710-9. doi: 10.3324/haematol.2018.207357

50. Langer AL, Leader A, Kim-Schulze S, Ginzburg Y, Merad M, Glassberg J. Inhaled steroids associated with decreased macrophage markers in nonasthmatic individuals with sickle cell disease in a randomized trial. Ann Hematol. (2019) 98:841-9. doi: 10.1007/s00277-019-03635-9

51. Gill FM, Sleeper LA, Weiner SJ, Brown AK, Bellevue R, Grover R, et al. Clinical events in the first decade in a cohort of infants with sickle cell disease. Cooperative Study of Sickle Cell Disease. Blood. (1995) 86:776-83. doi: 10.1182/blood.V86.2.776.bloodjournal862776
52. Overturf GD. Infections and immunizations of children with sickle cell disease. Adv Pediatr Infect Dis. (1999) 14:191-218.

53. Suara RO. Group A beta-haemolytic streptococcal acute chest event in a child with sickle cell anaemia. Ann Trop Paediatr. (2001) 21:175-8. doi: 10.1080/02724930120058278

54. Dean D, Neumayr L, Kelly DM, Ballas SK, Kleman K, Robertson S, et al. Chlamydia pneumoniae and acute chest syndrome in patients with sickle cell disease. J Pediatr Hematol Oncol. (2003) 25:46-55. doi: 10.1097/00043426-200301000-00010

55. Van Tuijn CF, Nur E, Van Beers EJ, Zaaijer HL, Biemond BJ. Acute chest syndrome in sickle cell disease due to the new influenza A (H1N1) virus infection. Am J Hematol. (2010) 85:303-4. doi: 10.1002/ajh. 21638

56. Rosch JW, Boyd AR, Hinojosa E, Pestina T, Hu Y, Persons DA, et al. Statins protect against fulminant pneumococcal infection and cytolysin toxicity in a mouse model of sickle cell disease. J Clin Invest. (2010) 120:627-35. doi: $10.1172 /$ JCI39843

57. Carter R, Wolf J, Van Opijnen T, Muller M, Obert C, Burnham $\mathrm{C}$, et al. Genomic analyses of pneumococci from children with sickle cell disease expose host-specific bacterial adaptations and deficits in current interventions. Cell Host Microbe. (2014) 15:587-99. doi: 10.1016/j.chom.2014.04.005

58. Karlsson EA, Oguin TH, Meliopoulos V, Iverson A, Broadnax A, Yoon SW, et al. Vascular permeability drives susceptibility to influenza infection in a murine model of sickle cell disease. Sci Rep. (2017) 7:43308. doi: $10.1038 /$ srep 43308

59. Ellison AM, Ota KV, Mcgowan KL, Smith-Whitley K. Pneumococcal bacteremia in a vaccinated pediatric sickle cell disease population. Pediatr Infect Dis J. (2012) 31:534-6. doi: 10.1097/INF.0b013e3182480fed

60. Santoro JD, Myers L, Kanter J. Assessing the immunogenic response of a single center's pneumococcal vaccination protocol in sickle cell disease. J Pediatr Hematol Oncol. (2016) 38:e102-6. doi: 10.1097/MPH.0000000000000510

61. Szczepanek SM, Roberts S, Rogers K, Cotte C, Adami AJ, Bracken SJ, et al. Poor long-term efficacy of prevnar-13 in sickle cell disease mice is associated with an inability to sustain pneumococcal-specific antibody titers. PLoS ONE. (2016) 11:e0149261. doi: 10.1371/journal.pone.0149261

62. Torres A, Blasi F, Dartois N, Akova M. Which individuals are at increased risk of pneumococcal disease and why? Impact of COPD, asthma, smoking, diabetes, and/or chronic heart disease on community-acquired pneumonia and invasive pneumococcal disease. Thorax. (2015) 70:984-9. doi: 10.1136/thoraxjnl-2015-206780

63. Han M, Rajput C, Ishikawa T, Jarman CR, Lee J, Hershenson MB. Small animal models of respiratory viral infection related to asthma. Viruses. (2018) 10:E682. doi: 10.3390/v10120682

64. Samarasinghe AE, Woolard SN, Boyd KL, Hoselton SA, Schuh JM, Mccullers JA. The immune profile associated with acute allergic asthma accelerates clearance of influenza virus. Immunol Cell Biol. (2014) 92:449-59. doi: 10.1038/icb.2013.113

65. Furuya Y, Furuya AK, Roberts S, Sanfilippo AM, Salmon SL, Metzger DW. Prevention of influenza virus-induced immunopathology by TGFbeta produced during allergic asthma. PLoS Pathog. (2015) 11:e1005180. doi: 10.1371/journal.ppat.1005180

66. Gaston MH, Verter JI, Woods G, Pegelow C, Kelleher J, Presbury $\mathrm{G}$, et al. Prophylaxis with oral penicillin in children with sickle cell anemia. A randomized trial. N Engl J Med. (1986) 314:1593-9. doi: 10.1056/NEJM198606193142501

67. Falletta JM, Woods GM, Verter JI, Buchanan GR, Pegelow CH, Iyer RV, et al. Discontinuing penicillin prophylaxis in children with sickle cell anemia. Prophylactic Penicillin Study II. J Pediatr. (1995) 127:685-90. doi: 10.1016/S0022-3476(95)70154-0

68. Adamkiewicz TV, Sarnaik S, Buchanan GR, Iyer RV, Miller ST, Pegelow $\mathrm{CH}$, et al. Invasive pneumococcal infections in children with sickle cell disease in the era of penicillin prophylaxis, antibiotic resistance, and 23valent pneumococcal polysaccharide vaccination. J Pediatr. (2003) 143:43844. doi: 10.1067/S0022-3476(03)00331-7

69. Mccavit TL, Gilbert M, Buchanan GR. Prophylactic penicillin after 5 years of age in patients with sickle cell disease: a survey of sickle cell disease experts. Pediatr Blood Cancer. (2013) 60:935-9. doi: 10.1002/pbc.24395 
70. Navalkele P, Ozgonenel B, Mcgrath E, Lephart P, Sarnaik S. Invasive pneumococcal disease in patients with sickle cell disease. J Pediatr Hematol Oncol. (2017) 39:341-4. doi: 10.1097/MPH.0000000000000858

71. Marra F, Lynd L, Coombes M, Richardson K, Legal M, Fitzgerald JM, et al. Does antibiotic exposure during infancy lead to development of asthma?: a systematic review and metaanalysis. Chest. (2006) 129:610-18. doi: 10.1378/chest.129.3.610

72. Reynolds LA, Finlay BB. A case for antibiotic perturbation of the microbiota leading to allergy development. Expert Rev Clin Immunol. (2013) 9:1019-30. doi: 10.1586/1744666X.2013.851603

73. Ortqvist AK, Lundholm C, Kieler H, Ludvigsson JF, Fall T, Ye W, et al. Antibiotics in fetal and early life and subsequent childhood asthma: nationwide population based study with sibling analysis. BMJ. (2014) 349:g6979. doi: 10.1136/bmj.g6979

74. Stokholm J, Sevelsted A, Bonnelykke K, Bisgaard H. Maternal propensity for infections and risk of childhood asthma: a registry-based cohort study. Lancet Respir Med. (2014) 2:631-7. doi: 10.1016/S2213-2600(14)70152-3

75. Pitter G, Ludvigsson JF, Romor P, Zanier L, Zanotti R, Simonato L, et al. Antibiotic exposure in the first year of life and later treated asthma, a population based birth cohort study of 143,000 children. Eur J Epidemiol. (2016) 31:85-94. doi: 10.1007/s10654-015-0038-1

76. Hirsch AG, Pollak J, Glass TA, Poulsen MN, Bailey-Davis L, Mowery J, et al. Early-life antibiotic use and subsequent diagnosis of food allergy and allergic diseases. Clin Exp Allergy. (2017) 47:236-44. doi: 10.1111/cea. 12807

77. Yamamoto-Hanada K, Yang L, Narita M, Saito H, Ohya Y. Influence of antibiotic use in early childhood on asthma and allergic diseases at age 5. Ann Allergy Asthma Immunol. (2017) 119:54-8. doi: 10.1016/j.anai.2017.05.013

78. Adami AJ, Bracken SJ, Guernsey LA, Rafti E, Maas KR, Graf J, et al. Earlylife antibiotics attenuate regulatory $\mathrm{T}$ cell generation and increase the severity of murine house dust mite-induced asthma. Pediatr Res. (2018) 84:426-34. doi: 10.1038/s41390-018-0031-y

79. Yoshida S, Ide K, Takeuchi M, Kawakami K. Prenatal and early-life antibiotic use and risk of childhood asthma: a retrospective cohort study. Pediatr Allergy Immunol. (2018) 29:490-5. doi: 10.1111/pai.12902

80. Murk W, Risnes KR, Bracken MB. Prenatal or early-life exposure to antibiotics and risk of childhood asthma: a systematic review. Pediatrics. (2011) 127:1125-38. doi: 10.1542/peds.2010-2092

81. Risnes KR, Belanger K, Murk W, Bracken MB. Antibiotic exposure by 6 months and asthma and allergy at 6 years: findings in a cohort of 1,401 US children. Am J Epidemiol. (2011) 173:310-8. doi: 10.1093/aje/ kwq400

82. Ver Heul A, Planer J, Kau AL. The human microbiota and asthma. Clin Rev Allergy Immunol. (2018) 57:350-63. doi: 10.1007/s12016-018-8719-7

83. Fukuda JT, Sonis AL, Platt OS, Kurth S. Acquisition of mutans streptococci and caries prevalence in pediatric sickle cell anemia patients receiving longterm antibiotic therapy. Pediatr Dent. (2005) 27:186-90.

84. Zeissig S, Blumberg RS. Life at the beginning: perturbation of the microbiota by antibiotics in early life and its role in health and disease. Nat Immunol. (2014) 15:307-10. doi: 10.1038/ni.2847

85. Schulfer A, Blaser MJ. Risks of antibiotic exposures early in life on the developing microbiome. PLoS Pathog. (2015) 11:e1004903. doi: 10.1371/journal.ppat.1004903

86. Lim SH, Morris A, Li K, Fitch AC, Fast L, Goldberg L, et al. Intestinal microbiome analysis revealed dysbiosis in sickle cell disease. Am J Hematol. (2018) 93:E91-3. doi: 10.1002/ajh.25019
87. Enwonwu CO, Xu XX, Turner E. Nitrogen metabolism in sickle cell anemia: free amino acids in plasma and urine. Am J Med Sci. (1990) 300:366-71. doi: 10.1097/00000441-199012000-00005

88. Morris CR, Kato GJ, Poljakovic M, Wang X, Blackwelder WC, Sachdev V, et al. Dysregulated arginine metabolism, hemolysis-associated pulmonary hypertension, and mortality in sickle cell disease. JAMA. (2005) 294:81-90. doi: 10.1001/jama.294.1.81

89. Morris CR, Kuypers FA, Larkin S, Vichinsky EP, Styles LA. Patterns of arginine and nitric oxide in patients with sickle cell disease with vaso-occlusive crisis and acute chest syndrome. J Pediatr Hematol Oncol. (2000) 22:515-20. doi: 10.1097/00043426-200011000-00009

90. Lopez BL, Kreshak AA, Morris CR, Davis-Moon L, Ballas SK, Ma XL. $\mathrm{L}$-arginine levels are diminished in adult acute vaso-occlusive sickle cell crisis in the emergency department. Br J Haematol. (2003) 120:532-4. doi: 10.1046/j.1365-2141.2003.04109.x

91. Morris CR, Kuypers FA, Lavrisha L, Ansari M, Sweeters N, Stewart M, et al. A randomized, placebo-controlled trial of arginine therapy for the treatment of children with sickle cell disease hospitalized with vaso-occlusive pain episodes. Haematologica. (2013) 98:1375-82. doi: 10.3324/haematol.2013.086637

92. Solomons C, Hathaway W, Cotton E. L-arginine, the sickling phenomenon, and cystic fibrosis. Pediatrics. (1972) 49:933.

93. Morris CR, Kuypers FA, Larkin S, Sweeters N, Simon J, Vichinsky EP, et al. Arginine therapy: a novel strategy to induce nitric oxide production in sickle cell disease. Br J Haematol. (2000) 111:498-500. doi: 10.1046/j.1365-2141.2000.02403.x

94. Morris CR. Alterations of the arginine metabolome in sickle cell disease: a growing rationale for arginine therapy. Hematol Oncol Clin North Am. (2014) 28:301-21. doi: 10.1016/j.hoc.2013.11.008

95. Bakshi N, Morris CR. The role of the arginine metabolome in pain implications for sickle cell disease. J Pain Res. (2016) 9:167-75. doi: $10.2147 /$ JPR.S55571

96. Cox SE, Ellins EA, Marealle AI, Newton CR, Soka D, Sasi P, et al. Readyto-use food supplement, with or without arginine and citrulline, with daily chloroquine in Tanzanian children with sickle-cell disease: a doubleblind, random order crossover trial. Lancet Haematol. (2018) 5:e147-60. doi: 10.1016/S2352-3026(18)30020-6

97. Saleh D, Ernst P, Lim S, Barnes PJ, Giaid A. Increased formation of the potent oxidant peroxynitrite in the airways of asthmatic patients is associated with induction of nitric oxide synthase: effect of inhaled glucocorticoid. FASEB J. (1998) 12:929-37. doi: 10.1096/fasebj.12.11.929

98. Mcbrien CN, Menzies-Gow A. The biology of eosinophils and their role in asthma. Front Med. (2017) 4:93. doi: 10.3389/fmed.2017.00093

99. Rath M, Muller I, Kropf P, Closs EI, Munder M. Metabolism via arginase or nitric oxide synthase: two competing arginine pathways in macrophages. Front Immunol. (2014) 5:532. doi: 10.3389/fimmu.2014.00532

Conflict of Interest: The authors declare that the research was conducted in the absence of any commercial or financial relationships that could be construed as a potential conflict of interest.

Copyright (๑) 2020 Samarasinghe and Rosch. This is an open-access article distributed under the terms of the Creative Commons Attribution License (CC BY). The use, distribution or reproduction in other forums is permitted, provided the original author(s) and the copyright owner(s) are credited and that the original publication in this journal is cited, in accordance with accepted academic practice. No use, distribution or reproduction is permitted which does not comply with these terms. 